\title{
Bセッション日本内科学会生涯教育講演会
}

\section{平成 10年度}

\section{II. 循環器 \\ 1. 循環器疾患と抗血栓療法 \\ 島田 和幸}

Key words：急性虚血症候群, 心不全, 心房細動, 抗血小板療法, 抗凝固療法

\section{はじめに}

循環器疾患の診療において，血栓症は次第に 大きな地位を占めつつある，不安定狭心症や急 性心筋梗塞など急性虚血症候群の直接の引き金 は, 冠動脈内壁の破綻から生じた壁在あるいは 閉塞血栓であることは今日よく理解されてい る. 如何にして冠動脈血栓の形成を予防し, 一 旦形成された血栓を如何に効率よく溶解するか が, 現在冠動脈疾患診療における中心的課題の 一つとなっている。 また，心不全，心筋症，心 室瘤, 弁膜症, 心房細動などにおいては, 心室 腔内の血栓が原因で生じる塞栓症が患者の予後 に大きな影響を及ほす，従って，内科臨床医に とっては, 各々の病態に扔ける血栓生成のメ力 ニズムを知り，従来からある，あるいは新しく 開発されつつある各種抗血栓薬の作用機序やそ の臨床的評価を熟知しておかねばならない.

\section{1. 血栓形成機序}

血栓生成の 3 大条件は, 血管壁損傷, 血中因 子の異常と血流の停滞である. 抗血栓治療は, その病態が血小板あるいは凝固系の活性化のど ちらがプライマリーなのかを見極めることが極 めて重要である，血管壁障害が発端となる動脈 血栓には血小板血栓（白色血栓）が，血中因子

しまだ かずゅ：自治医科大学唱環器内科
の異常や血流停滞が主因となる静脈・心室内血 栓にはフィブリンの豊富な㠜固血栓 (赤色血栓) が形成される．図１に血栓形成の分子機序とし て，血小板活性化および凝固系カスケード反応 の模式図を示す”．血小板は血管壁あるいは血 小板同士，GPIbயaのような糖蛋白接着分子 を介して付着・凝集する。そしてそれらの反応 はトロンビン，トロンボキサンなどの生理活性 物質によって刺激され活性化される。一方, 凝 固系は組織因子・第VII因子によって反応が開 始される外因系と接触因子の活性化などによっ て開始される内因系があるが，いずれも血小板 膜表面で反応が進み，最終的には第X因子の活 性化によりプロトロンビンからトロンビンが形 成される．第VIU因子や第V因子はりん脂質膜 上で活性化第IX, X因子の反応を触媒するコ ファクターである.

抗血栓療法として用いられるアスピリンはト ロンボキサンの生成を阻害し，チクロピジンや シロスタゾールは血小板内の活性化機構を阻害 する. 一方, ヘパリンは血中のアンチトロンビ ンIIIと結合してトロンビンや第X因子を不活化 し，ワルファリンは肝蔵での凝固因子生成過程 （II，VI，IX，X因子）を阻害することにより 凝固を抑制する。理論的には，図10各段階で 血栓形成を阻害することが可能であり，害際， GPIIbIaの阻害薬は現在最も強力な抗血小板 薬であり，第X因子やトロンビンの直接的な阻 


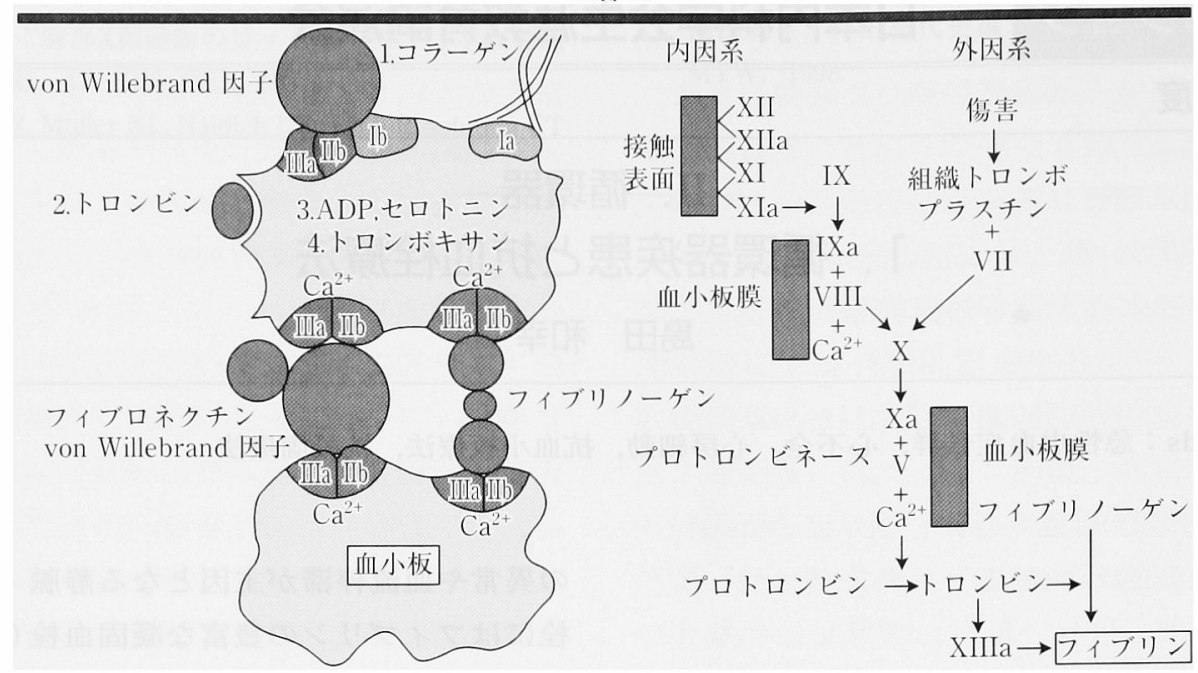

図1. 血栓形成の分子機序 (文献 1 より引用)

害薬が既に開発されている．抗血栓作用のもう 一つのアプローチは天然の抗凝固系（プロテイ ンCやトロンボモジュリン)の臨床応用である.

\section{2. 急性虚血症候群}

動脈壁プラークの脆弱性は, 動脈硬化巣プ ラークの構成成分と血流などの機械的因子によ り決定される．動脈硬化プラークは，何らかの ストレスが加わると破綻し, 壁在血栓が生成さ れ，不安定狭心症や急性心筋梗塞などの急性虚 血症候群などの臨床病態を招来する ${ }^{21}$. 血管内 腔を完全閉塞する程の大量の血栓が生じた場合 が急性心筋梗塞であり，血管を狭乍するが完全 閉塞には至らない状態で留まっている状態が不 安定狭心症である，血管内視鏡で観察すると， 予想通り前者は赤色血栓, 後者は白色血栓がみ られるという3゙.

不安定狭心症患者にアスピリンを投与して, 血小板活性化指標とともに生体内トロンビン活 性の指標が抑制されたという成績が国立循環器 病センターから報告されている"). すなわち， この場合の血栓形成は血小板系の活性化が主因 で, 凝固系は 2 次的に刺激された病態と考えら
表 1 .

$$
\begin{aligned}
& \text { 不安定狭心症 血小板血栓 } \\
& \text { アスピリン } \quad \text { 初回 } 160 \sim 325 \mathrm{mg} \\
& \text { 以後 } 80 \mathrm{mg} / \text { 日 } \\
& \text { (チクロピジン } 200 \sim 300 \mathrm{mg} \text { ) } \\
& \text { ヘパリン } 5000 \text { 単位静注 } \\
& \text { 点滴(APTT } 60 \text { - } 80 \text { 秒) }
\end{aligned}
$$

急性心筋梗塞 凝固血栓

血栓溶解療法, アスピリン, ヘパリン

れる，不安定狭心症のアスピリン量は $75 \mathrm{mg} /$ 日 程度の少量でよいとされている5! 急性心筋梗 塞が発症した場合は凝固血栓を溶解する必要が あり，プラスミノゲンを活性化する血栓溶解薬 の投与が適応となる（表 1 ).

\section{3. 急性心筋梗塞後}

急性心筋梗塞に陥った心筋局所は, dyskinesisや心室瘤を形成し，心尖部に壁在血栓を生 じ，それが塞栓症の原因となることがある。そ のために広範な急性前壁梗塞や心室瘤, 心内血 栓を合併した症例には, 一定期間の抗凝固療法 が推奨されている）（表 2 ）。

我々は, 急性心筋梗塞後の左室内血栓の生成 
表 2. 急性心筋梗塞後の血栓塞栓症

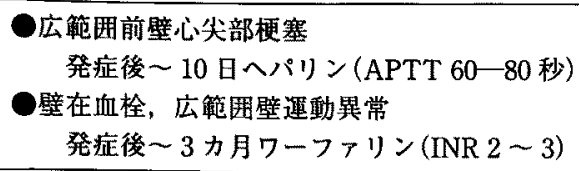

頻度を経時的に心エコーで観察した．その結果 は，陽性所見を示す頻度が欧米では20〜 50\%に 達するのに比し，10\%以下に留まり，塞栓症の 出現頻度も極めて低かった，すなわち，日本人 は血栓形成傾向が欧米人に比し弱く，このこと は逆に出血傾向が高いことを意味する可能性が ある，従って，我々は欧米の文献を瓶吞みにす ることには慎重でなくてはならず, 独自の抗凝 血学的療法の指針を作成する必要がある.

\section{4. 心不全}

心不全も血栓塞栓症の大きなりスク要因であ る. 我々が肥大型心筋症や拡張型心筋症の患者 の血中凝血学的マーカーを検討した結果でも， 生体内トロンビン活性の立進が認められた ${ }^{7}$.

しかも, 収縮機能不全の場合は心室径や駆出率 と, 拡張不全の病態の場合は左房径とそれらが よく相関しており，それぞれの血栓生成刺激の 亢進している心室腔が異なっていることが推測 された。ささらに慢性の虚血性心疾患患者の駆出 率と凝血学的マーカーもよく相関した ${ }^{81}$.

実際にどの程度の塞栓症を心不全患者が発症 しているかについては, ACE (アンジオテン シン変換酵素）阻害薬などの心不全に対する各 種大規模臨床試験の成績が参考となる. それに よると年間 1 ～ $2 \%$ で決して高い数字ではない が,これらの臨床試験では抗凝固療法は必要に 応じて施行されており, それらの治療効果が反 映されているものと思われる9!.

心不全に心房細動が合併されていれば，抗凝 固療法の適応である. 洞調律の場合は，アスピ リンの効果は疑わしく, 著しい心機能低下のあ る患者では抗凝固療法を行った方がよいとする
表 3. 心不全と抗血栓療法

O洞調律
血栓塞栓症のリスク増加
アスピリン: 無効?
EF35\%以下 : 抗凝固療法?
心房細動
抗凝固療法

考えもある（表 $3 ）$.

\section{5. 非弁膜症性心房細動}

心房細動の基礎心疾患は, 社会環境の変化や 人口の高齢化に伴い, リウマチ性弁膜症が減少 する一方, 高血圧性心疾患, 冠動脈疾患, 心筇 症，先天性心疾患，甲状腺疾患などを基盤とす る非弁膜症性心房細動 (non-valvular atrial fibrillation, NVAF）が增加し, これらが心房細 動の原因の約 $60 \%$ を占めるに至っている.これ らは, 特に高齢者に多発し, 高齢者の重要な脳 塞栓症の原因となっている.NVAFの抗血栓療 法に関するいくつかの大規模臨床試験の成績に 基づいて，心房細動の合併症としての塞栓症に 対するリスク因子が同定された. それれにる と，1）高血圧の既往，2）脳卒中/TIAの既往,

3）糖尿病，4）65歳以上,5）心不全の5つが 塞栓症の発症の独立した有意な予測因子であっ た. 狭心症, 心筋梗塞などの冠動脈疾患は, 独 立した危険因子ではないが，その合併はさらに 脳塞栓症のリスクを増加させる。これら臨床的 リスク因子以外に，心エコー上のパラメータも 重要である.すなわち, 左房の拡大, 左室機能 不全が加わると，それがない場合に比して約 5 倍の塞栓症発症のリスク增大となる，従って心 エコーの所見も無症状の患者には参考となる。

近年, NVAFの抗血栓療法に関する無作為臨 床治験成績が相次いで報告された。これらの臨 休試験を通じて, NVAFに対して, ワーファリ ンによる抗凝固療法は, 塞栓症の発生を少なく とも60\%以上減少させることが明らかとなっ た.しかも出血の副作用はリスク軽減に対し容 


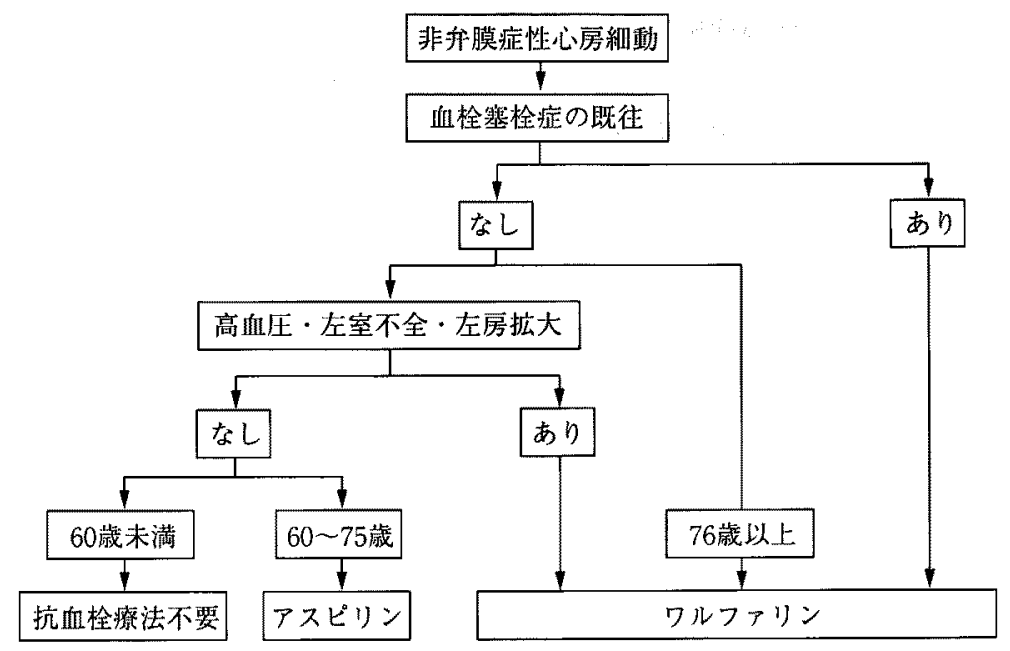

図 2. 非弁膜症性心房細動患者における抗血栓療法の適応基準

(内山真一郎：非升膜症性心房細動一megatrialからのレッスン. Heart View 1997;1: 466-470より引用)

認できる程度のものであった。一方，アスピリ ンには $20 \%$ 程度のリスク減少率しかなく，明ら かに抗凝固療法が優先される。しかし，若年者 は，元来塞栓症のリスクが低く，抗凝固療法は 効果に比し出血の副作用が無視できないと思わ れる.どのような患者に抗凝固療法を，どのよ うな患者に抗血小板療法を施行すべきかについ ては図 2 に示すアルゴリズムが提唱されてい る.76歳以上では, 全体のイベントは増加した が，ワーファリン群で年間3.6\%，アスピリン 群で $4.8 \%$ とワーファリンがより有効であった が, 脳出血の頻度がワーファリン群 $4.2 \%$, ア スピリン群 $1.6 \%$ で，高齢者における抗凝固療 法の危険性が強調された（図 2 ）。塞栓症に対 するハイリスク因子, 高血圧の既往, 脳卒中/ TIAの睍往, 75歳以上, 心不全のうちどれかが 該当する患者にはワーファリンを投与し，これ らが存在しないローリスク患者には，抗血小板 薬を投与する．場合によってはリスクが極めて 低い患者には経過観察だけですますか，60〜75 歳の中程度のリスク群には抗凝固療法を考慮す る.

\section{6. 抗血栓療法}

ワーファリンによる抗凝固療法の強度はINR (international normalized ratio) 2 3が欧米の 標準であるが，わが国では通常INRが1.5〜2.5 (トロンボテスト10～25\%) でコントロールし ているのが実状である．我が国においても，八 イリスクの患者にはINR 2.0は維持する方が無 難であろう． INR 3.0以上は出血の危険がある． その他に抗凝固療法中の出血性副作用を起こし やすい要因として，75歳以上の高齢者，著明な 高血圧, 大酒家, INRがよく変動する患者は特 に注意する必要がある.もしワーファリンが投 与できないときは抗血小板薬を投与する.

抗血小板薬については, アスピリンが一般的 であるが, チクロピジンなど他の薬剤も使用で きる.アスピリン量については，議論があり， 特に脳卒中に対しては80〜325mgと幅がある.

\section{文献}

1) Fuster $V$, et al: Atherosclerotic plaque rupture and thrombosis: evolving concept. Circulation 82 (Suppl II) : II-47, 1990 
2）由谷親夫：Acute coronary syndromeの発生機序. Medical Practice $14: 1888,1997$

3) Mizuno K, et al : Angioscopic evaluation of coronary artery thrombi in acute coronary syndromes. $\mathrm{N}$ Engl J Med 326: 287, 1992

4) Yasu $T$, et al: Effects of aspirin DL-Lysine on thrombin generation in unstable angina pectoris. Am J Cardiol $71: 1164,1993$

5）西山信一郎, 岩瀬孝 : 不安定狭心症と抗血小板・抗凝 固療法. 医学のあゆみ $167: 572,1993$

6) Meltzer RS, et al:Intracardiac thrombi and systemic embolization. Ann Intern Med 104:689, 1986

7) Yamamoto $K$, et al: Coagulation is activated in idiopathic cardiomyopathy. J Am Coll Cardiol 25:1634, 1995

8) Yamamoto $\mathrm{K}$, et al : Left ventricular function and coagulation activity in healed myocardial infarction. Am J Cardiol $81: 920,1998$

9) Cleland J: Anticoagulant and antiplatelet therapy in heart failure. Curr Opinion Cardiol 12:276, 1997

10）島田和幸：心原細動と脳塞栓. 日医雑誌 $118: 1701$, 1997 